\title{
Influence of Decomposed Wood Sawdust on Growth and Yield of Foreign F1 (Thorgal and Mongal) Hybrid Varieties of Tomato (Solanum lycopersicum L.) Grown Under Kisangani Shelter (D.R Congo)
}

Lokonga O. , Tonganga K.

Department of Biotechnological Sciences, Faculty of Science, B.P. 2012, University of Kisangani, DR Congo

DOI: $10.36348 / \mathrm{sb} .2020 . v 06 i 05.001$

| Received: 22.04.2020 | Accepted: 03.05.2020 | Published: 10.05.2020

*Corresponding author: Lokonga $\mathrm{O}$.

\section{Abstract}

Within the framework of this work, the objective was to evaluate the performance of two hybrid varieties F1 (Thorgal and Mongal) foreign of tomato (Solanum lycopersicum L), with the use of saw dusts of wood decomposes, cultivated under shelter with Kisangani. It A was undertaken with an aim of improved the production of tomato with large fruit. The experimental culture used for the two varieties was a device of the blocks randomized at a rate of 3 repetitions per piece. The observation on the two hybrids F1 Thorgal and Mongal) carried on some quantitative characters in particular the average weight of fruits, the compartmental production and the output. For the hybrids F1 (Thorgal and Mongal) cultivated in the ground enriched by sawdust of wood:

- $\quad$ The average fruit weight was higher with the variety $\mathrm{T}(92 \mathrm{~g})$ and less low with the variety $\mathrm{T}(78 \mathrm{~g})$;

- The compartmental production was higher with the variety $\mathrm{M}(15 \mathrm{~kg})$ and less low with the variety with the variety $\mathrm{T}(8,1 \mathrm{~kg})$ and

- The output was slightly higher than the variety $\mathrm{T}(3,7$ tones/ha) and slightly lower than the variety $\mathrm{M}(3,1$ tones/ha).

For the hybrid variety F1 THORGAL and its witness

- the average weight was slightly high with the pilot variety To $(93 \mathrm{~g})$ and slightly less less high with the variety T $(92 \mathrm{~g})$

- $\quad$ The compartmental production ranked above the witness To $(9,4 \mathrm{~kg})$ and lower than the variety $\mathrm{T}(8,1 \mathrm{~kg})$ and

- The output was identical to the variety $\mathrm{T}$ and its witness To (3, 7 tones/ha).

For the hybrid F1 Mongal cultivated in the ground enriched by saw dusts by wood and its witness

- The weight was higher with the variety M (78 G) and less low with its witness Mo (74 G);

- The compartmental production was higher with the variety M (15 kg) and less low with its witness Mo (7,9 kg) and

- The output was slightly higher than the variety M $(3,1)$ and slightly lower than the variety Mo (3 tones/ha).

The results obtained by these two hybrid varieties F1 (Thorgal and Mongal) show that the foreign varieties of tomato had two forms: form round observed with the variety $\mathrm{T}$ and form flattened with the Mr. variety As for the checking of our assumptions, the variety $\mathrm{M}$ is more powerful than the variety $\mathrm{T}$ enriched by saw dusts of wood. The influence of saw dusts of wood for the variety $\mathrm{T}$ did not have the impact.

Keywords: Influence, Sawdust, Wood, Growth, Yield, Varieties, F1 Hybrids, Thorgal, Mongal, Foreign, Tomato, Solanum lycopersicum $L$.

Copyright @ 2020: This is an open-access article distributed under the terms of the Creative Commons Attribution license which permits unrestricted use, distribution, and reproduction in any medium for non-commercial use (NonCommercial, or CC-BY-NC) provided the original author and source are credited.

\section{INTRODUCTION}

Tomato is one of the most widespread crops in the world. It is a very important source of vitamins and an important income crop for smallholders and commercial farmers with medium-sized operations.
Tomato cultivation is an advantageous activity for many rural, urban and peri-urban producers [1-6].

In the climatic conditions of the Kisangani region, the cultivation of exotic tomatoes poses a number of problems. These problems include poor 
adaptation to the climate, as well as susceptibility to diseases and pests. For these reasons and those related to the very limited income of the population, it is therefore the local varieties of tomato with low quality yield, but better adapted to the conditions of the environment, that are grown and sold on the local market. Despite the difficulties encountered, foreign varieties are increasingly appreciated by the population than the local variety. Hence the need to test the agronomic performance of new commercial varieties.

Lately the large tomatoes observed in the Kisangani market come from North Kivu Province. From then on, so-called F1 hybrid varieties appeared that gradually supplanted the fixed old lineages, they are obtained from genetically distant homozygotic lines and the cross-breeding gives the offspring an increased vigor in the face of a given character, called hybrid vigor or heterocyst [7-12].

The use of hybridization in agriculture has increased considerably in recent decades, particularly in vegetable plants. In 1995 , more than $80 \%$ of tomato varieties were from hybrids of older varieties. As early as the 1970, breeders sought to increase tomato production yields through crossbreeding between different varieties [13-16].

In addition to their increased performance, hybrids are more homogeneous than parent varieties: plants from the cross-breeding of two pure lines and selected because of their hybrid vigor will be selected so much that they will be genetically identical $[5,15-$ $18]$. Indeed, the production of the selected varieties are influenced by their own genetic potentialities and the environment, the growing conditions in which these potentialities materialize, i.e. their genotypes [13, 14, 19]. For tomatoes, there are two main types of crops $[15,20]$. "Field" cultivation is the classic crop that has no protection from the effects of the climate. "Undersheltered" cultivation is a technique that protects plants through shelter; it requires permanent irrigation. For a "under-sheltered, full-earth" crop, the soil is preserved, whereas in the case of a "sheltered, above ground" crop, production is either on an inert substrate or without substrate (Nutrient Film Technology or NFT, aeroponics, aquaponics...).

In this type of crop, it is necessary to have permanent fertilizing irrigation (nutrient solution) [2023].

During the rainy season that characterizes the humid tropical climate, waterlogged soils cannot be cultivated and rains, by their impact, destroy plants and fruits while facilitating the development of fungal diseases in particular. In such a climate, the production of vegetable crops is therefore limited. However, the high population density observed in both urban and peri-urban areas leads to a high demand for vegetables $[20,24]$. To increase vegetable production in these regions, it is therefore necessary to be able to circumvent the constraints associated with the high rainfall of the humid tropical climate.

In this context, sheltering is an interesting technique: it protects plants from rain and thus allows production throughout the year [20]. In addition, this type of cultivation allows the development of aboveground or hydroponic production and thus removes certain constraints related to the nature of the soil: mineral deficiencies, inadequate physical structure, presence of pathogens [20]. Finally, through better control of diseases and hydro mineral nutrition, sheltered cultivation promotes higher yields than field crops and better-presented fruits and therefore easier to value. It allows for increased production on smaller surfaces [20].

The use of shelter also tends to protect plants from the already very high temperatures recorded in tropical environments. At the same time, the radiation that reaches these crops is reduced by the roofing material, the palm branches; plastic film most of the time. Indeed, various climate changes with rising higher temperatures require diversification of agricultural practices, including sheltered cultivation $[20,25]$. The major consequence of climate change for tropical and Mediterranean agriculture will be increased risk of drought. Drought is also the most consequential constraint faced by most farmers in the world each year [26-29].

The consequences of drought vary greatly depending on the intensification of agriculture and agricultural practices.

Agricultural practices are the first cover of drought risk. The techniques used are mainly aimed at strengthening the ability of soils to maintain fertility in times of drought. The main market garden species that have an advantage to be grown under shelter all year round are tomatoes, lettuce, peppers, zucchini, beans and condiments including onions. To make this facility profitable, the farmer will have to carry out an intensive crop under this shelter; this assumes that it will maintain good soil fertility, whether chemical, physical or biological [20,21]. Organic fertilization includes all organic amendments, organic fertilizers and oreganomineral fertilizers, whether natural or synthetic [20, 21]. This allows tomato yield to be improved by organic fertilizers.

The overall objective is to assess the performance of two F1 hybrid varieties for sawing from sheltered wood. The specific objective of this work is to: Detect the most efficient F1 hybrid variety for the use of sawdust. The aim of this work is to improve 
Lokonga O. \& Tonganga K., Sch Bull, May, 2020; 6(5): 105-122

tomato production and its interest lies in the recycling of industrial waste from the primary wood processing industry (Sawmills), which reduces environmental pollution. Industrial waste of plant origin (wood sawdust) poses environmental problems in the industrial sector of Kisangani. We are committed to making this industrial plant waste the noble products of agriculture. This is part of our commitment to promote agriculture that respects the environment and contributes to the preservation of the living environment. This work exploits these industrial plant products to boost agricultural yields, especially tomatoes.

\section{MATERIELS AND METHODS VEGETAL MATERIEL}

The plant material used consists mainly of two commercial tomato varieties that are: F1Thorgal and F1 Mongal. These varieties are represented by Figures 1 and 2 below:

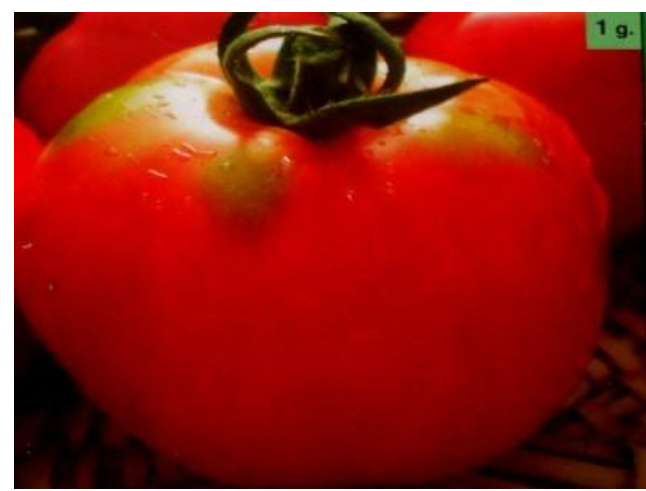

Fig-1: F1Thorgal

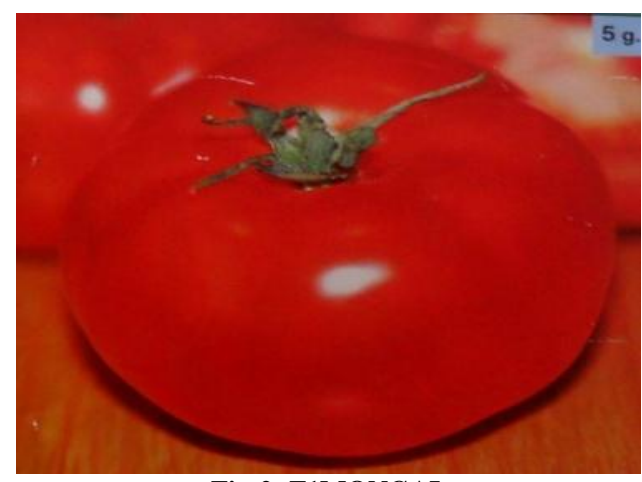

Fig-2: F1MONGAL

The seeding was carried out in the grounds of the Faculty of Science under shelter on 2/05/2016, the shelter was made of palm branches (Elaeis guineensis). The nursery germinal 2 meters long by 1 meter wide, containing the foreign hybrid varieties $\mathrm{F} 1 \mathrm{~T}$ and $\mathrm{M}$. The transplant was performed 30 days after sowing $(01 / 06 / 2016)$, at a rate of 16 feet per randomized block. The space between the plants was $50 \mathrm{~cm} \mathrm{x}$ $50 \mathrm{~cm}$.Interviews were conducted on a regular basis while carrying out the facts such as: weeding; tutoring and watering. The number of seeds for each variety was 130.For both varieties, the experimental randomized block system was adopted due to two seals in the order of 3 liters of sawdust to amend the soil. The characterization involved $\mathrm{F} 1$ hybrids in 3 repetitions (blocks) of two treatments each.

Treatments have been defined as follows: $\mathrm{T}$ : Hybrid F1 Thorgal grown in the enriched block of sawdust; To: hybrid F1Thorgal control grown in the un enriched block of sawdust; M: F1Mongal hybrid grown in the enriched block of sawdust; Mo: hybrid F1Mongal control grown in the un enriched block of sawdust; The 2 plots measured 8 meters each and each block had an area of $4 \mathrm{~m}^{2}(2 \mathrm{~m} \times 2 \mathrm{~m})$ and the spreads used were $5 \times 5 \mathrm{M}$. The walkways between the blocks and the plots were $0,50 \mathrm{M}$. The seedlings produced in germinationnursery were transplanted to the 30th day after seeding according to the randomized block device. Observations of the plant set focused on the rate of growth, the number of flowers and fruits, and the analysis of the fruit consisting of color, weight, number of seminal lodges, fruit length and width, total number seeds and the shape index.

For each fruit, the following observations were made:

- The color of the fruit.

- The number of seminal lodges.

- The weight of the fruit.

- The height and width of the fruit.

- The total number of seeds, including welldeveloped and poorly developed seeds.

\section{The Shape Index (S I) [30]}

The color of the fruit was observed with the naked eye. The weight of the fruit was obtained using the KERN-branded precision scale. The number of seminal lodges was counted after the cross-section of the fruit. The height and width were measured by a sliding foot. The number of seeds was counted after reopening for at least 24 hours in the test tube.

The fruit shape was determined by the shape index (FDI) obtained by the following relationship:

$$
\mathrm{I} . \mathrm{F}=\frac{\text { fruit hieght }}{\text { fruit diameter }}[30-32]
$$

Thus, the fruits were grouped into three series:

- Round Fruit: : $0,80<$ I.F $<1,20$

- $\quad$ Flattened Fruits: I.F. $<0,8$

- $\quad$ Elongated Fruit: : I.F. $>1,20$

Parcel production and yield were calculated by extrapolation.

\section{STATISTICAL DATA}

The data was processed with R.210 software.

The evaluation of F1 hybrids is given by Figure-3 below: 


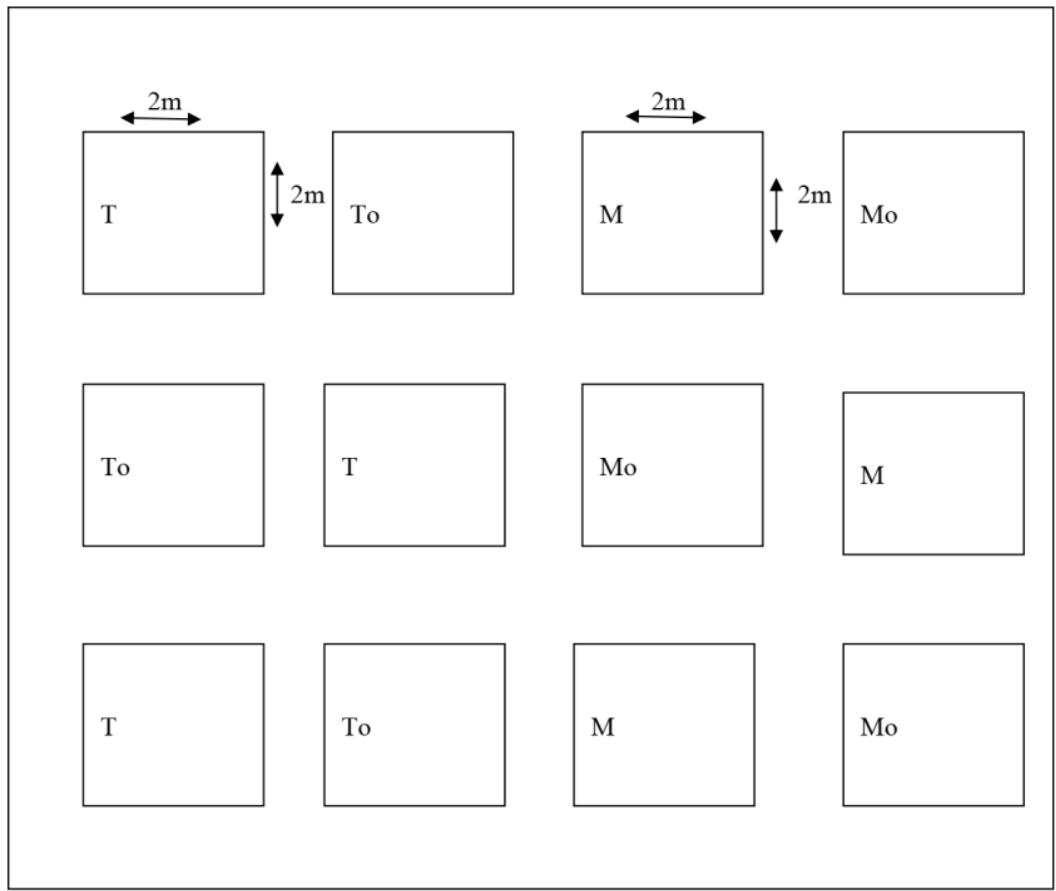

Fig-3: Evaluation of hybrid varieties F1T and M.

Legend:

T: THORGAL in sawdust;

To: Witness THORGAL;

M: MONGAL in sawdust;

Mo: Witness MONGAL;

\section{RESULTS AND DISCUSIONS}

The results of various analyses and observations made during this work on two hybrid varieties of tomatoes grown under shelter are represented in Figure 4 to 31 and Table-1.

\section{ANALYSIS OF SOME QUANTITATIVE CHARACTERISTICS}

Quantitative characters of the hybrid varieties F1THORGAL and MONGAL.

\section{LEVEE RATE}

The lifting rate of the hybrid varieties $\mathrm{F} 1$ THORGAL (T) and MONGAL (M) is presented in Figure-4.

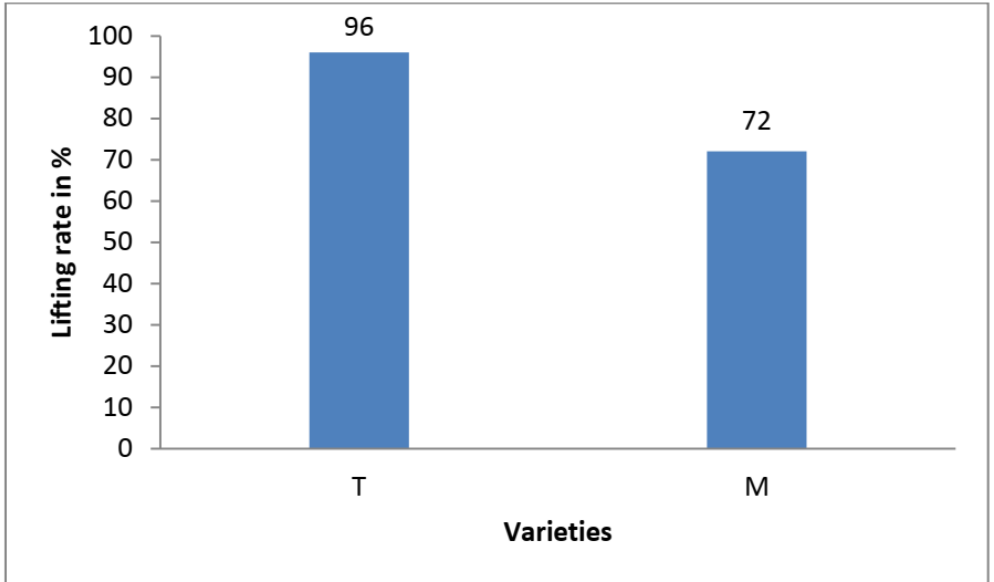

Fig-4: The lifting rate of the hybrid varieties F1 THORGAL and MONGAL

Legend: M - hybrid variety F1 MONGAL and T - hybrid variety F1THORGAL

Figure-6 shows that the lifting percentage ranged from $72 \%$ to $96 \%$. The $\mathrm{T}$ variety grown in soil enriched with sawdust had the highest survey rate. This discrepancy between the two varieties under experimentation is due to genotypes.
Compared to the results of Bokolo [22], which observed the germination rate for the Marmande variety of $11.5 \%$. This difference is believed to be due to the cultivars used and the conditions of experimentation. 
Also comparing our results with those of Lokonga and Kamara [34], which found the survey rate of $70 \%$ for the THORGAL variety and $97.6 \%$ for the MONGAL variety, grown in the soil of pig manure. Small differences can be attributed to the culture medium.

\section{Medium Plant Size}

The medium size of hybrid varieties $\mathrm{F} 1 \mathrm{~T}$ and $\mathrm{M}$ is presented in Figure-5.

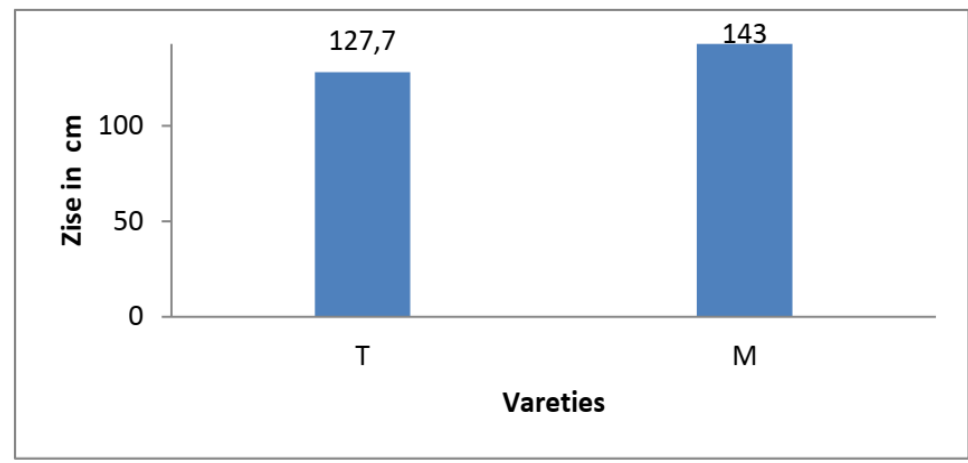

Fig-5: Medium size of the hybrid varieties F1 T and M

It shows in Figure-5 that the medium size of the hybrid $\mathrm{M}$ variety is higher $(143 \mathrm{~cm})$ than the $\mathrm{T}$ variety $(127.7 \mathrm{~cm})$. The statistical test of student carried out by the R.210 software shows that there is no significant difference between the hybrid varieties F1 T and $\mathrm{M}(\mathrm{p}$ - value $=0,34>0,05)$.
Comparing our results with those of Lokonga and Kamara [34], which found for the variety $M$ $(127.83 \mathrm{~cm})$ and $\mathrm{T}(129.83 \mathrm{~cm}$ respectively), this difference is explained by environmental conditions.

\section{Average number of flowers per plant}

The average number of flowers per plant of the hybrid varieties F1 T and M is illustrated in Figure-6.

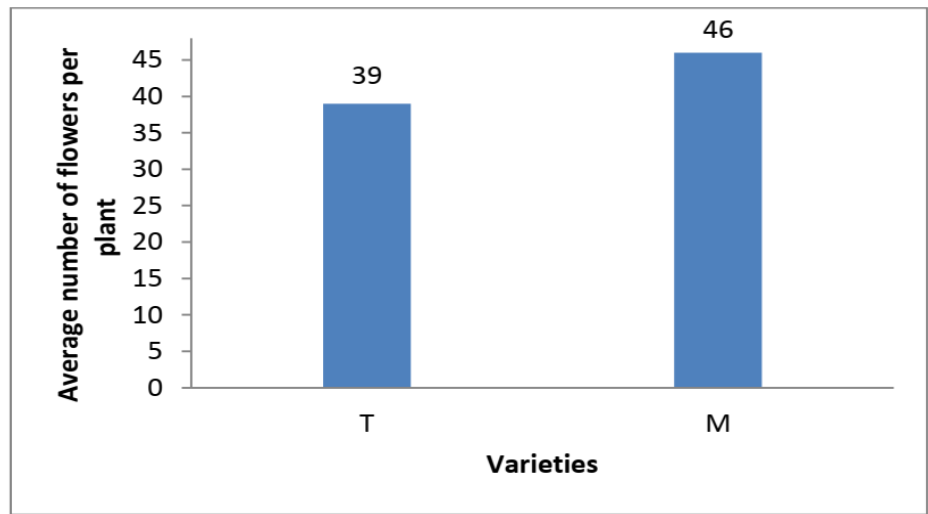

Fig-6: Average number of flowers of hybrid varieties F1 T and M

It is shown in Figure 6 that the average flower production ranged from 39 to 46 flowers. The $M$ variety produced more (46 flowers) than the $\mathrm{T}$ variety (39 flowers). These average numerical values subjected to the static student test do not reveal a significant difference between the two varieties ( $\mathrm{p}$-value $=0,12$ > $0,05)$

Comparing our results with those of Lokonga and Kamara [34], which worked on the same varieties but grown in soil enriched with pig manure. He observed for the T variety (31.66 flowers) and for the $\mathrm{M}$ variety (27.91 flowers). It is clear that our values are higher. The discrepancy between these results could be explained by the conditions of the environment.

\section{Average number of fruits per plant}

The average number of fruits of hybrid varieties $\mathrm{F} 1 \mathrm{~T}$ and $\mathrm{M}$ is presented in Figure-7. 


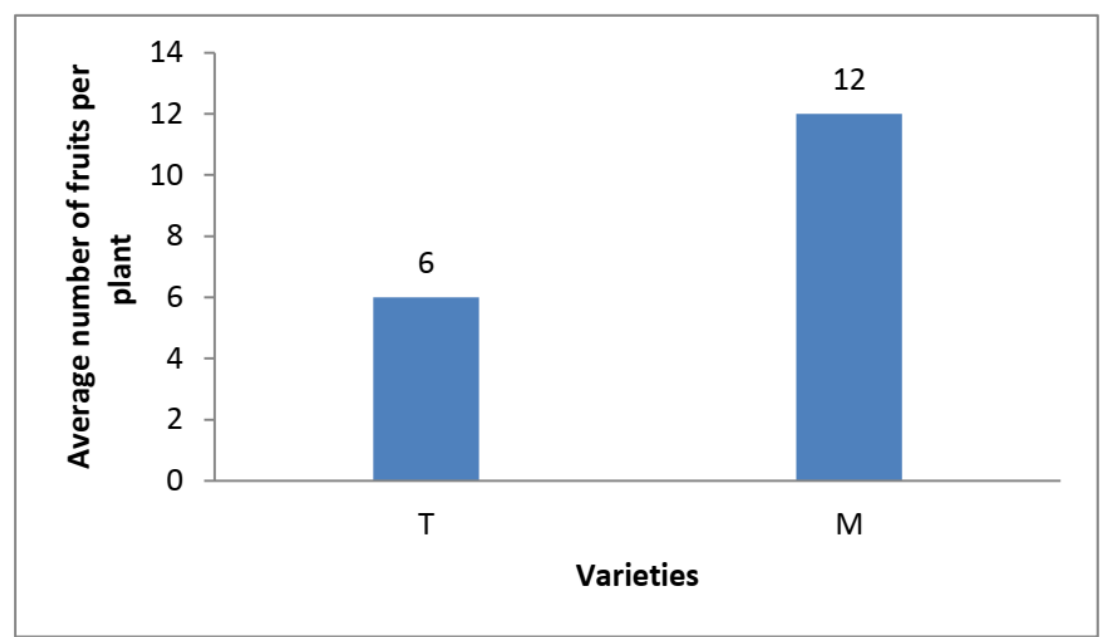

Fig-7: Average fruit number per plant of hybrids $T$ and $M$

Figure-7 shows that the number of fruits varied on average from 6 to 12 . The $M$ variety has knotted more fruit (12) than the T variety (6). The statistical test of the student applied to these results shows that there is no significant difference $(\mathrm{p}$-value $=0,21>0.05$ ).

Referring to the results of Lokonga and Kamara [34], we note that the $\mathrm{T}$ variety grown in the soil of pig manure is lower (4.58 fruits). This difference may be to the growing conditions.

\section{Average fruit weight}

The average fruit weight of the hybrid varieties $\mathrm{F} 1 \mathrm{~T}$ and $\mathrm{M}$ is presented in Figure-8.

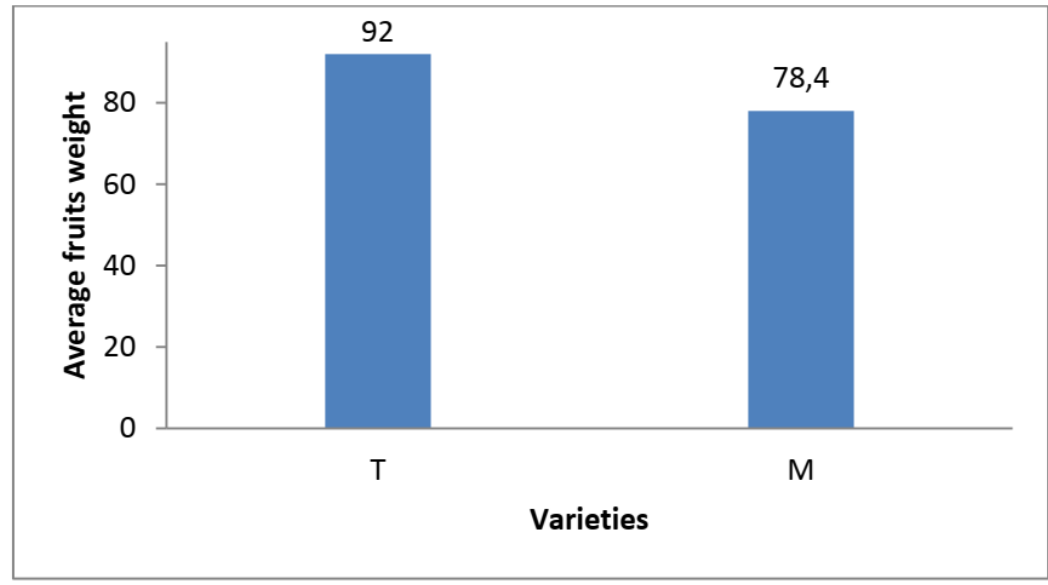

Fig-8: Average fruit weight of $\mathrm{F} 1 \mathrm{~T}$ and $\mathrm{M}$ hybrids

Figure- 8 shows that the weight of the F1 T hybrid variety is higher $(92 \mathrm{~g})$ compared to the $\mathrm{M}$ variety $(78.4 \mathrm{~g})$. The statistical student test applied to these results does not show a difference.

The statistical test of the student applied to these results does not show a significant difference ( $\mathrm{p}$ value $=0,72>0,05)$. Compared to the results of Lokonga and Kamara [34], which found for the M variety grown in pig manure-like soil $(79.92 \mathrm{~g})$, this value is slightly higher. The fruit weight of the $T$ variety grown in soil enriched with pig manure (82.53) is lower. This difference is related to the growing conditions.

\section{Average number of lodge per fruit}

The average number of hybrid $\mathrm{F} 1 \mathrm{~T}$ and $\mathrm{M}$ varieties is illustrated in Figure-9. 


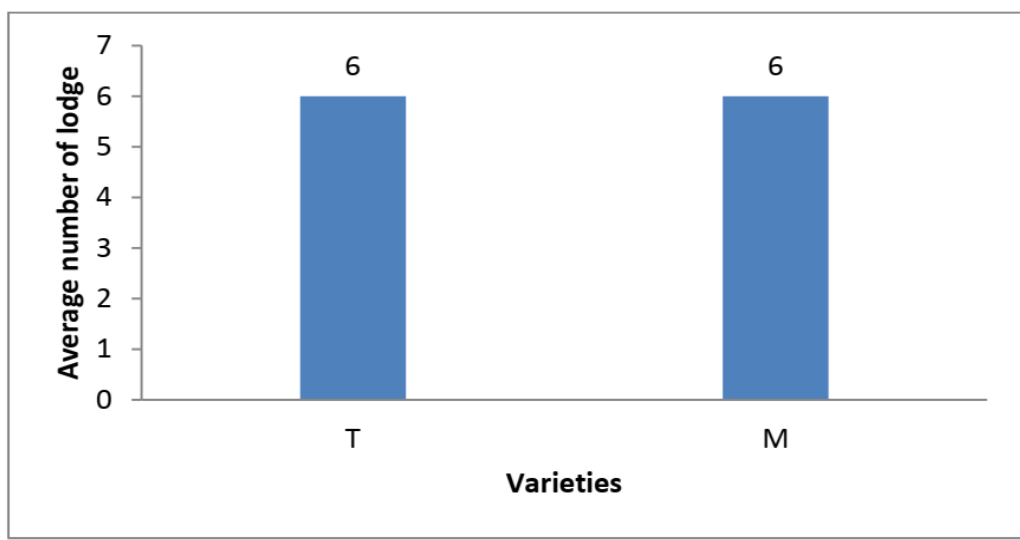

Fig-9: Average number of F1 T and M hybrid hybrids

Figure-9 shows that the number of boxes of the $\mathrm{T}$ variety is the same as the $\mathrm{M}$ variety (6 lodges). Comparing our results to those of Lokonga [16], which found for the hybrid variety F1 group XI the average number of lodges (2.23 lodges). Our hybrid varieties contain more lodges. This difference can be explained by the varieties used and probably by the growing conditions.

\section{Shape Index}

The analysis of the form index is illustrated in Figure-10 below:

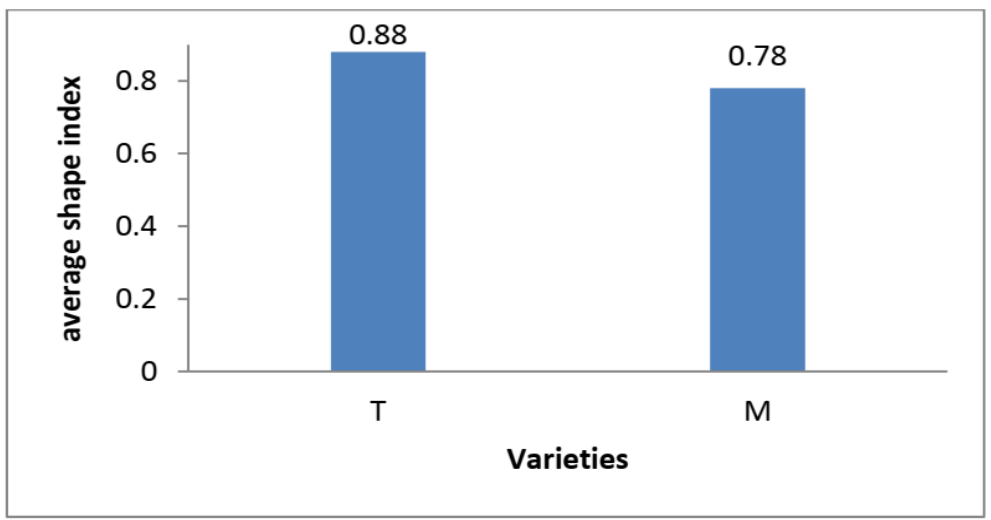

Fig-10: Fruit Shape Index of hybrid varieties F1 T and M

Figure-10 shows that the form index ranged from 0.78 to 0.88 . And shows that the fruits of the $\mathrm{M}$ variety are flattened and those of $\mathrm{T}$ are round. These results are consistent with normal values ranging from 0.8 to 1.20 for the round form; lower than $(0.8)$ for the flattened shape and greater than (1.20) for an elongated shape.

\section{Number of well-formed seeds}

The number of well-formed seeds of hybrid F1 varieties is presented in Figure-11.

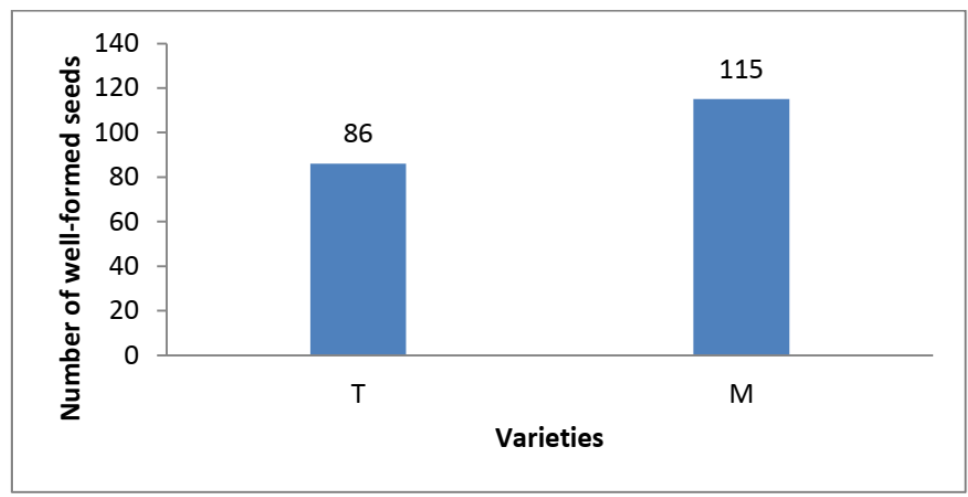

Fig-11: Average number of well-formed seeds of hybrid varieties F1 T and $M$ 
Figure-11 shows that the average number of well-formed seeds has been observed in the $M$ variety (115 seeds). On the other hand, the T variety developed fewer seeds (86 seeds).

Compared to the results of Bokolo [33], which obtained the average well-formed seeds of 35.6 seeds, this value is lower than our values. This difference can be attributed to the genotypes of the varieties used and the conditions of experimentation.

\section{Parcel Production}

The parcel production of hybrid varieties F1 T and $\mathrm{M}$ is presented in Figure-12.

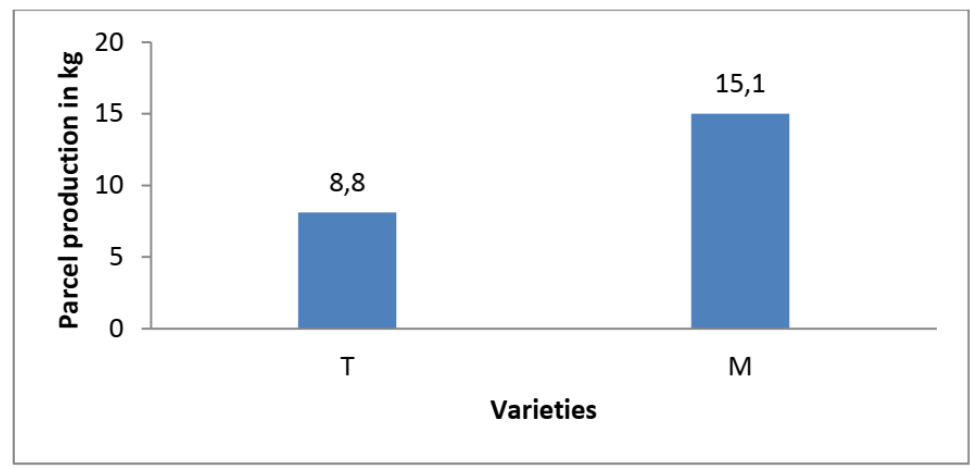

Fig-12: Parcel production (in kg)

The observation of Figure-12 reveals that parcel production was higher in the $\mathrm{T}$ variety $(15.1 \mathrm{~kg})$ and lower in the $\mathrm{M}$ variety $(8.8 \mathrm{~kg})$. Comparing our results to those of Lokonga [16], which obtained for the variety $\mathrm{F} 6 / \mathrm{G} 10(4.5 \mathrm{Kg})$ group XIV and for F6/G14 $(6.1 \mathrm{~kg})$ group XIV. Our results are superior. These differences can be explained on the one hand by the genotypes of the varieties and, on the other hand, by the conditions of the environments.

\section{Fruit yield}

The yield of fruits of hybrid varieties $\mathrm{T}$ and $\mathrm{M}$ is illustrated in Figure-13.

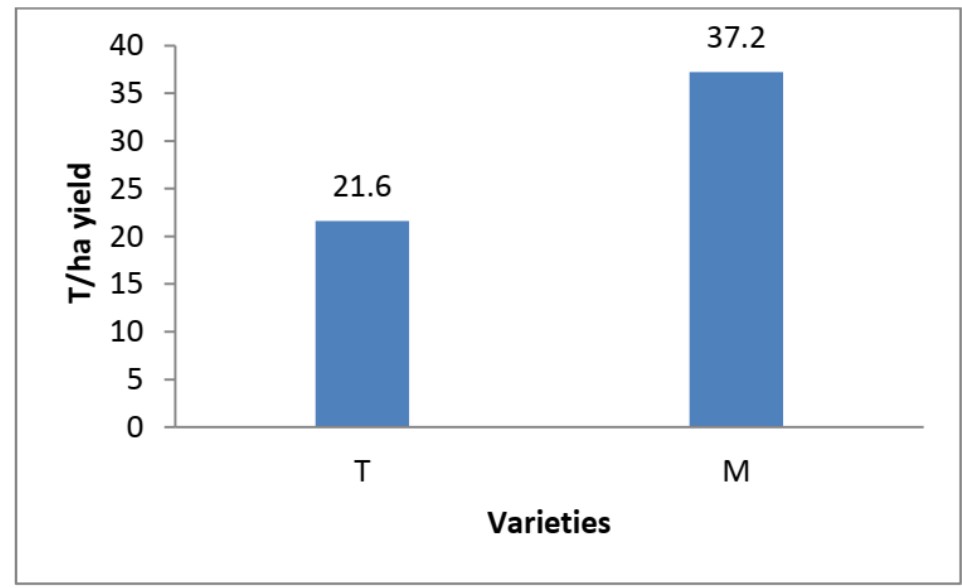

Fig-13: Fruit yield of hybrid varieties $F 1 \mathrm{~T}$ and $\mathrm{M}$

Legend: ha - hectare, $\mathrm{t}$ - tons.

Figure-13 shows that the yield ranged from 21.6 to 37.2 tonnes. The $\mathrm{M}$ variety yielded a higher yield (37.2t/ha) compared to $\mathrm{T}(21.6 \mathrm{t} / \mathrm{ha})$. Comparing our results to those of Lokonga and Kamara [34] who have found for the $\mathrm{M}$ variety $(15.11 \mathrm{t} / \mathrm{ha})$ and the $\mathrm{T}$ variety $(14.61 \mathrm{t} / \mathrm{ha})$. This shows that the $M$ variety grown in soil enriched with sawdust is superior to the same variety grown in soil enriched with pig manure. As for the $\mathrm{T}$ variety grown in soil enriched with pig manure, is lower than the same variety grown in soil enriched with sawdust. This discrepancy can be attributed to environmental conditions.

\section{Quantitatives characters of the variety F1THORGAL (T) and ITS WITNESS (To)}

Average size of plants the average size of plants of the hybrid variety F1 THORGAL cultivated in the soil enriched with sawdust $(\mathrm{T})$ and not enriched (To) be presented in Figure-14. 


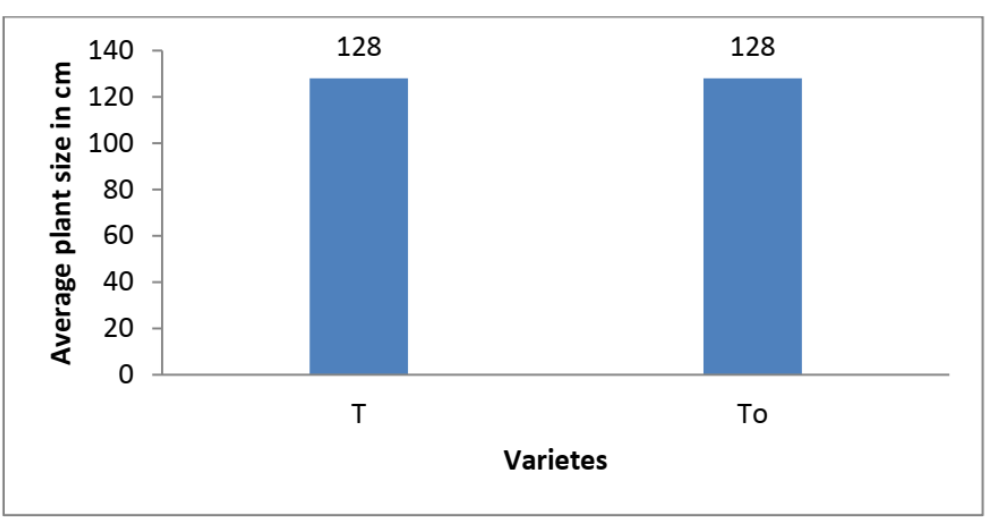

Fig-14: Average size of hybrid variety $\mathrm{F} 1, \mathrm{~T}$ and To

Legend: $\mathrm{T}=\mathrm{THORGAL}$ and $\mathrm{To}=$ witness THORGAL;

It appears from this Figure-14 that the average size of plant is identical $(128 \mathrm{~cm})$ in the two conditions. The statistical test of student of hybrid variety F1 T and its control To, shows that there is no significant difference $(p-$ value $=0.96>0.05)$. Compared to the results of Lokonga [16], who found for the hybrid variety $\mathrm{F} 1$ of group XI $(128.26 \mathrm{~cm})$. This slight difference is related to the genotypes and the conditions of the culture medium.

\section{Average number of flowers per plant}

The number of flowers of the hybrid variety $\mathrm{F} 1$ THORGAL cultivated in the soil enriched with sawdust (T) and unenriched (To) is presented in Figure-15.

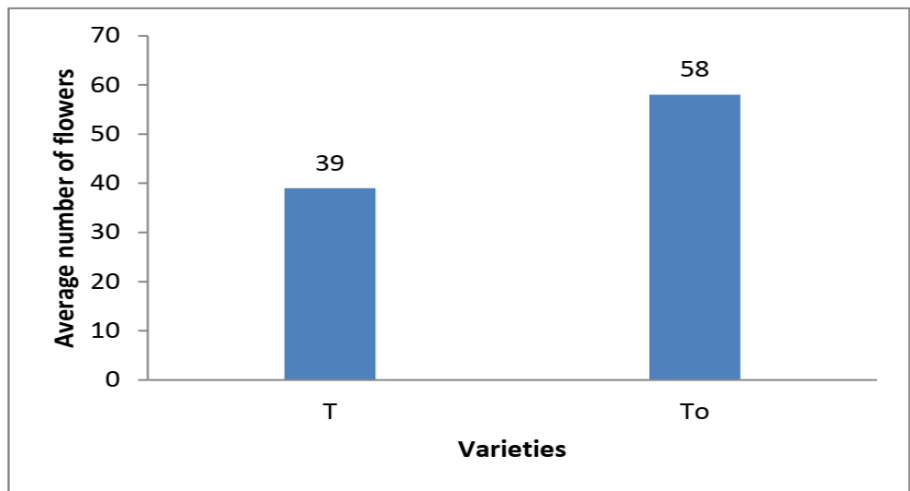

Fig-15: The number of flowers per plant of the hybrid variety $\mathrm{F} 1 \mathrm{~T}$ and the control To

It appears from this Figure-15 that the average number of flowers varied from 39 to 58 flowers. The witness developed more flowers than the variety grown in the enriched soil. The student test carried out by software R. 2.10 showed that there is no significant difference $(\mathrm{p}-$ value $=0.07>0.05)$. By comparing our results to those of Lokonga [16], who found for the hybrid variety F1 of group XI (55.8 flowers). This value is greater than the variety $\mathrm{F} 1 \mathrm{~T}$ and is less than its control. This difference is due to genotypes and environmental conditions.

Number of fruits per plant the number of $\mathrm{T}$ and to hybrid variety fruits is shown in Figure-16.

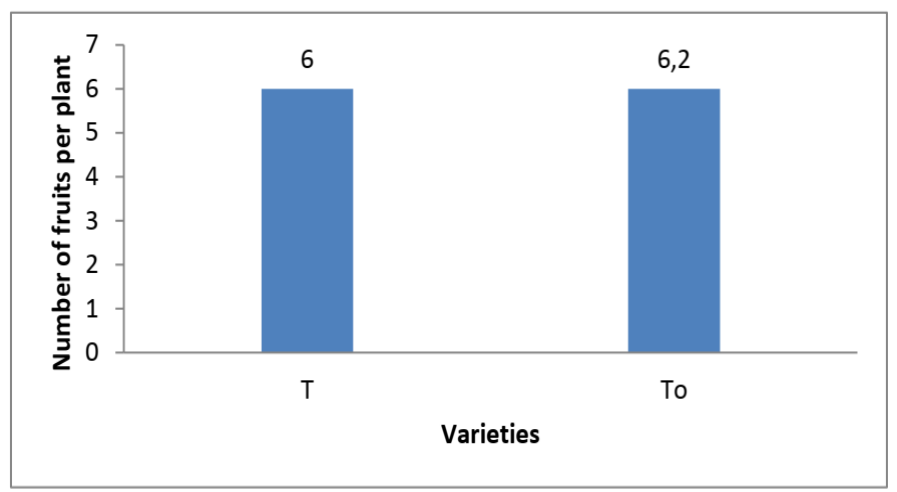

Fig-16: Numbers of fruits of the hybrid variety $T$ and To 
From the examination of this Figure-16, it emerges that the control variety To is slightly higher (6.2 fruits) than the variety $\mathrm{T}$ cultivated in the soil enriched with sawdust (6). The student test performed by software R. 2.10 showed that there is no significant difference $(p$-value $=0.72>0.05)$. By comparing our results to those of Lokonga [16], who found for the hybrid variety F1 (15.5 fruits) of group XII. Our values are lower. This performance can be explained, on the one hand, by the genotypes of the varieties studied and, on the other hand, by the environment.

\section{Average fruit weight per plant}

The average weight of the fruit of the hybrid variety $\mathrm{T}$ and To is illustrated in Figure-17.

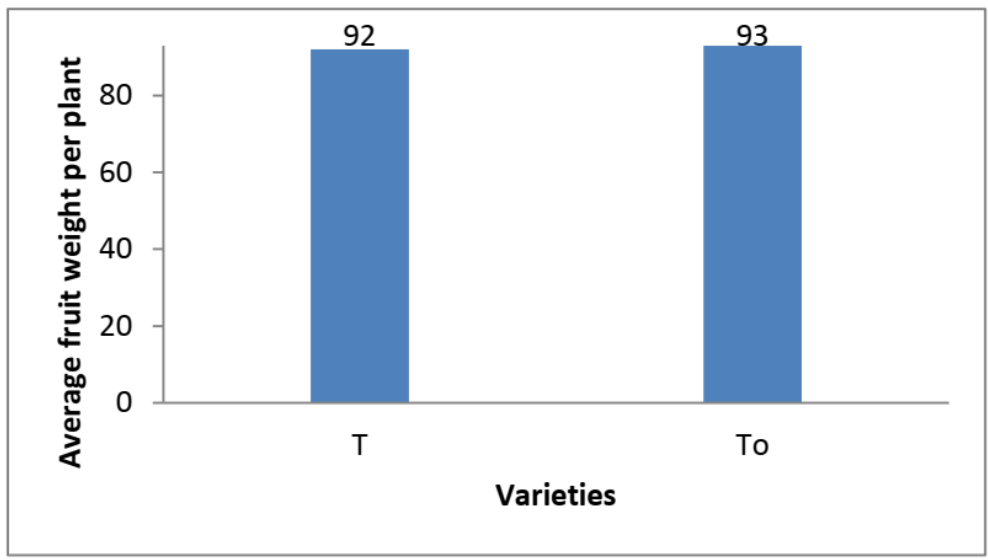

Fig-17: Average weight of hybrid variety F1T and To

It appears from this Figure-17 that the average fruit weight is slightly higher in the control To $(93 \mathrm{~g})$ than $\mathrm{T}$ in enriched medium $(92 \mathrm{~g})$. The student test applied to these data shows that there is no significant difference $(\mathrm{p}$-value $=0.91>0.05)$.

By comparing these results to those of Lokonga [16], who obtained the average weight of hybrid variety F1 (32.13) from group XI. This value is lower than our results. These differences in weight could be due to environmental conditions, cultural practices and the varieties used.

\section{Average number of lodges per plant}

The number of lodges per hybrid variety plants $\mathrm{F} 1 \mathrm{~T}$ and To is given in Figure-18.

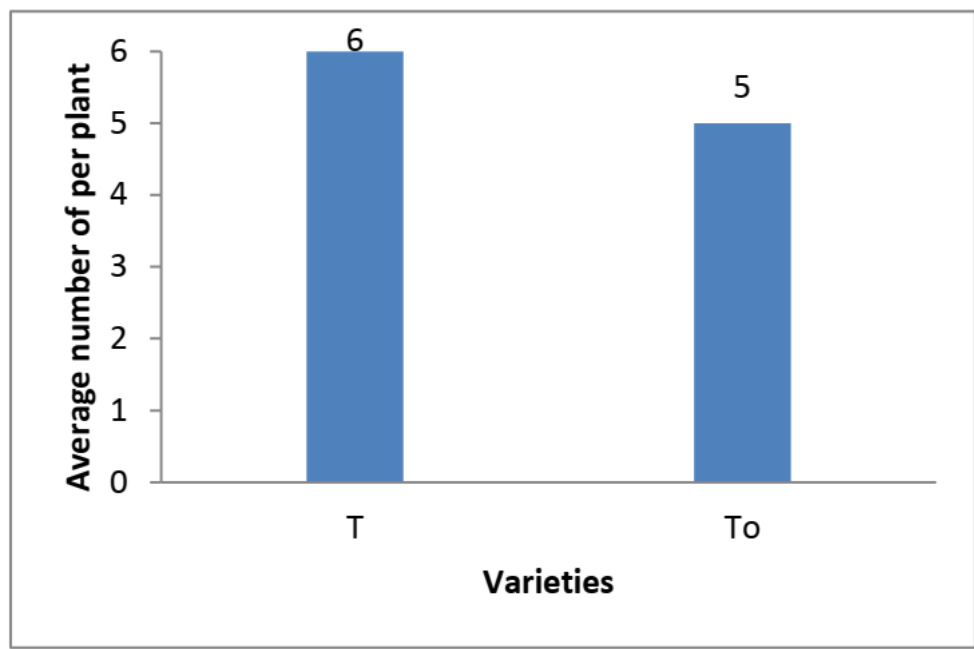

Fig-18: average number of lodges per fruit of the hybrid varieties $\mathrm{F} 1 \mathrm{~T}$ and To

It appears from this Figure-18 that the variety $\mathrm{T}$ presented ( 6 boxes) and control To ( 5 boxes). By comparing our results to those of [16] the number of lodges of the hybrid variety F1 (3.17) of group X. This value is lower than our results. These differences are explained by genotype and cultural conditions.

\section{Shape Index}

The $\mathrm{T}$ and To hybrid variety fruit shape index is shown in Figure-19. 


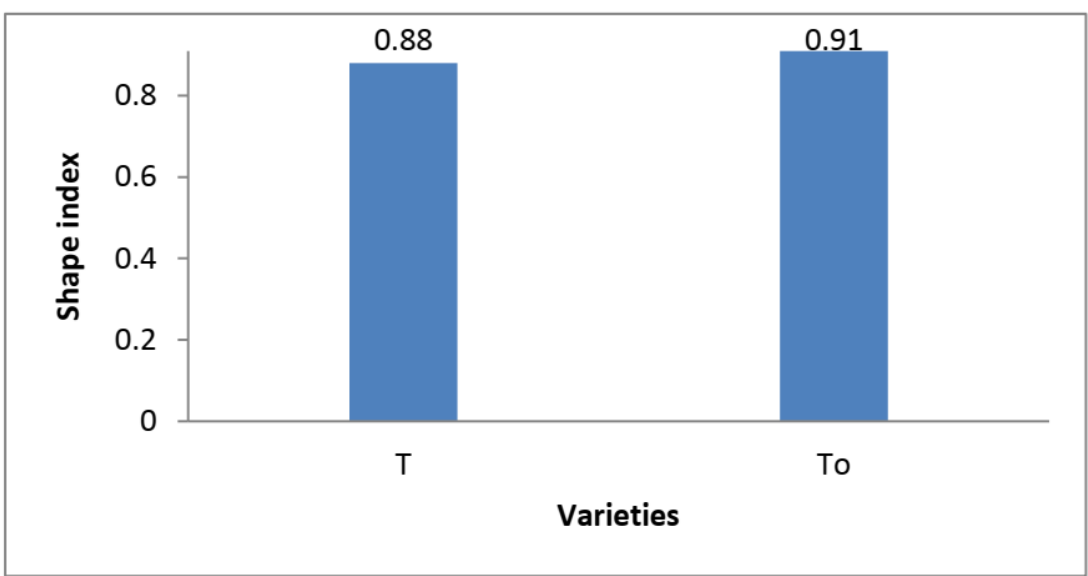

Fig-19: shape indices of hybrid varieties $T$ and To

From the examination of this Figure-19, it emerges that all the fruits are round in the same variety under the two conditions.
Average number of well-formed seeds

The average number of well-formed grains of the hybrid variety $\mathrm{F} 1 \mathrm{~T}$ and To is illustrated in Figure20 .

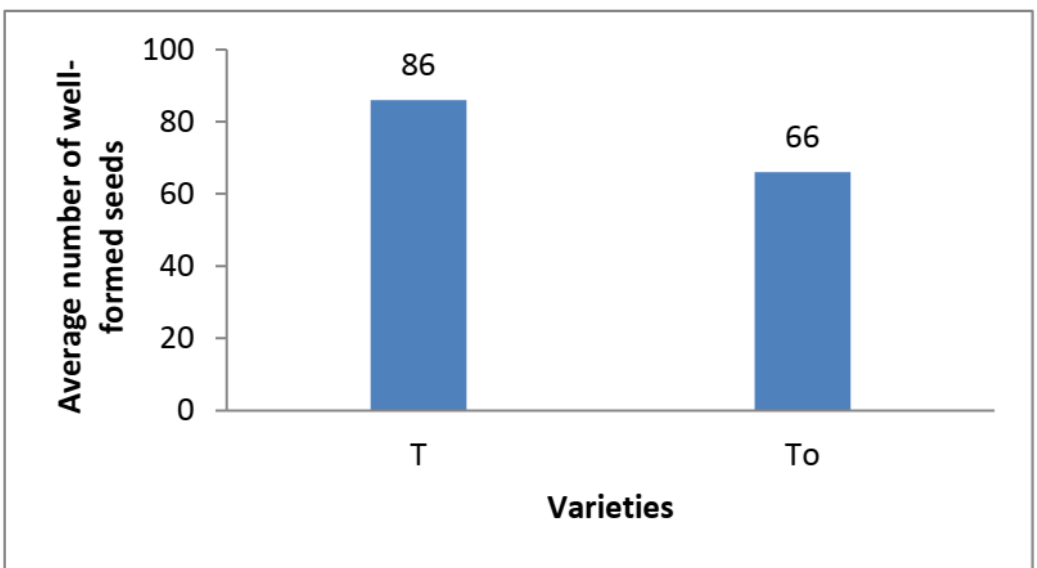

Fig-20: The average number of well-formed grains of hybrid variety $\mathrm{F} 1 \mathrm{~T}$ and To

It can be seen from this figure 20 that the number of well-formed seeds varied from 66 to 86 seeds. By comparing our results to those of Bokolo [33], who found 56.8 seeds in the variety MARMANDE. This number is lower. This difference may be due to genotypes and environmental conditions.

\section{Plot Production}

The plot production of hybrid variety $\mathrm{F} 1 \mathrm{~T}$ and To is shown in Figure-21.

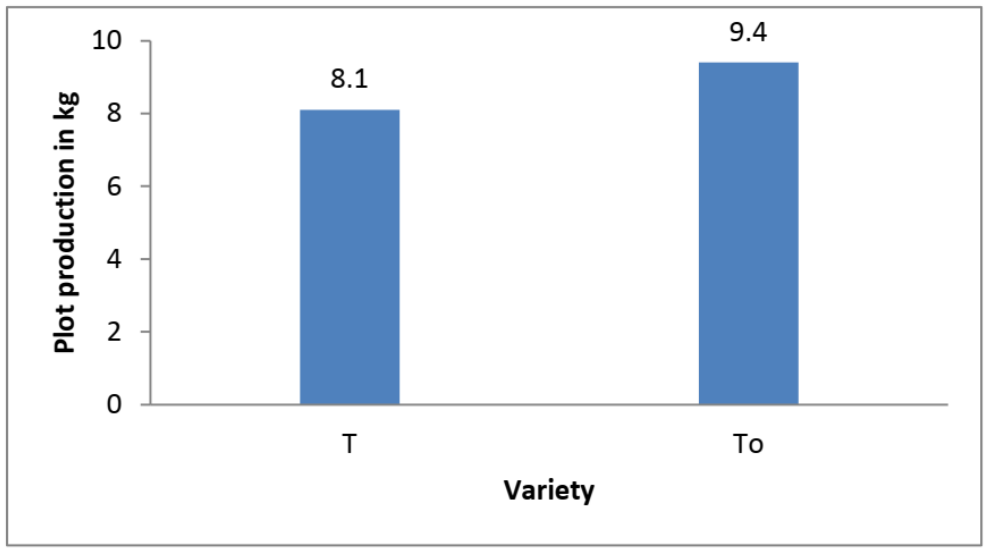

Fig-21: Plot production of hybrid variety $\mathrm{F} 1 \mathrm{~T}$ and To 
The observation in Figure-21 shows that the plot production is higher in the control $(9.4 \mathrm{~kg})$ and less in the same variety cultivated in the soil enriched with sawdust $(8.1 \mathrm{~kg})$. Referring to the results of Lokonga [16], who found for the hybrid variety F6 / G10 (4.5 kg) of group XIV. This result is lower than our results. This difference may be due to genotypes and environmental conditions.

Yield

The fruit yield of the hybrid variety $\mathrm{F} 1 \mathrm{~T}$ and its control To is illustrated in Fig-22.

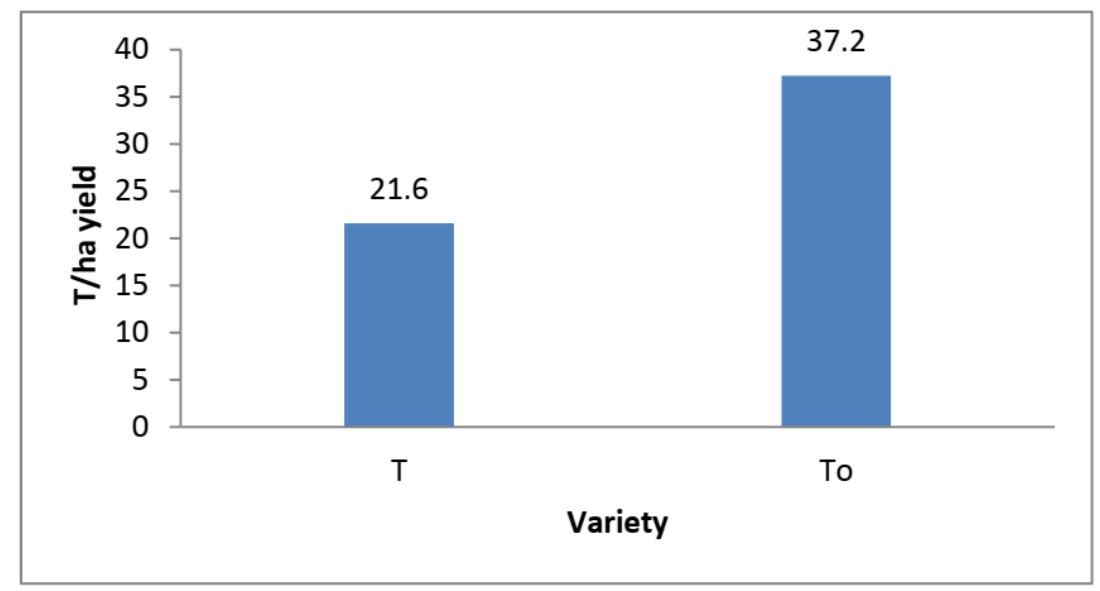

Fig-22: Yield of F1 T hybrid and To control fruit

The observation in Figure-22 shows that the yield of the control variety To is higher (37.2 t / ha) compared to the variety $\mathrm{T}$ cultivated in soil enriched with sawdust (21.6t / ha). By comparing our results with those of Lokonga and Kamara [34], who found for the hybrid control F1 variety To (14.72t / ha) and T grown in pig manure (14.61t / ha) lower than the cultivated $\mathrm{T}$ variety in the soil enriched with sawdust and its witness. These differences are explained by environmental conditions.

\section{Quantitative characters of the variety F1MONGAL (M) AND ITS WITNESS (MB) \\ Average size per plant \\ The average size of the hybrid variety F1 M} and Mo is shown in Figure-23.

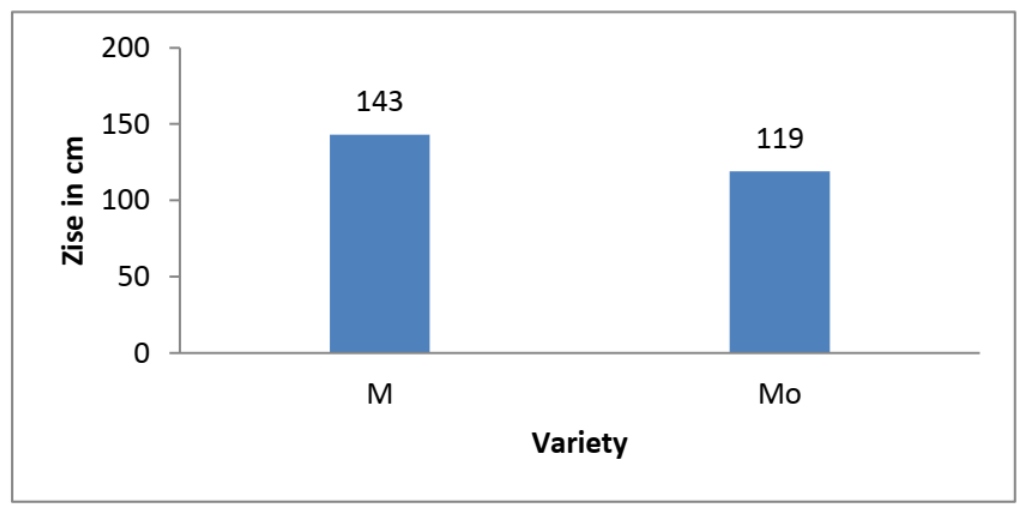

Fig-23: The average size of the F1M hybrid variety and of the witness Mo

Legend: $\mathrm{M}=$ MONGAL and $\mathrm{Mo}=$ witness

It appears from Fig-23 that the average size of the hybrid variety F1 M and its control Mo varied from 119 to $143 \mathrm{~cm}$. The MONGAL F1 variety cultivated in soil enriched with sawdust presented the largest size than the control. However, the student statistical test shows that there is no significant difference $(\mathrm{p}$ - value $=$ $0.03<0.05$ ). By comparing our results with those of Lokonga [16], who obtained for the hybrid variety F1 of group XIV $(89.6 \mathrm{~cm})$. This shows that the variety $\mathrm{M}$ cultivated in the soil enriched with sawdust and its witness is superior. This difference is due to genotypes and environmental conditions.

\section{Average number of flowers per plant}

The average number of flowers per plant of the hybrid variety F1 (M) and its control (Mo) is marked in Figure-24. 


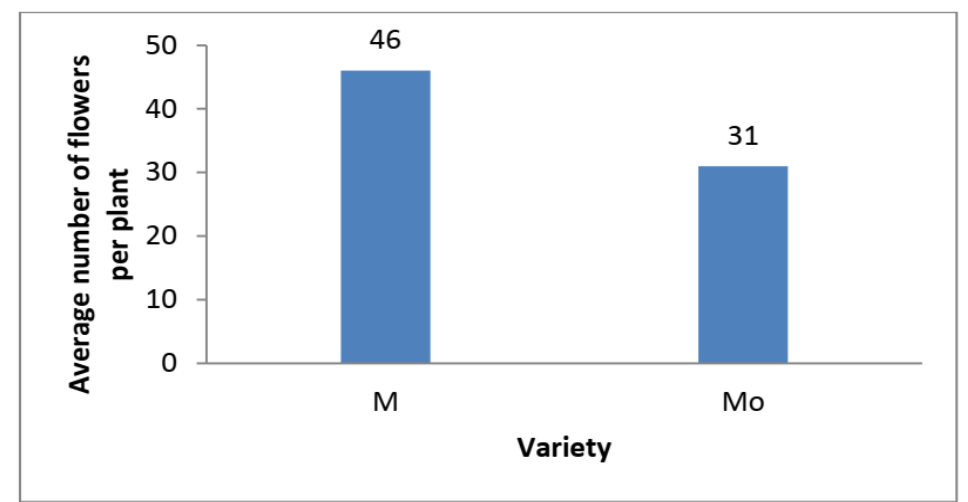

Fig-24: Average number of flowers per plant of hybrid variety F1 M and witness Mo

It can be seen from this Figure-24 that the average number of flowers per plant of the hybrid variety F1 varied from 31 to 46 flowers under the two culture conditions. The applied student statistical test shows that there is no significant difference $(\mathrm{p}-$ value $=$ $0.12>0.05$ ). By comparing our results to those of Lokonga [16] who found for the hybrid variety F1 (45.9) group $X$. This shows that this result is greater than the control $\mathrm{M}$ and is less than the variety $\mathrm{M}$ cultivated in the soil amended with sawdust. This difference may be due to genotypes and cultural conditions.

\section{Average number of fruits per plant}

The number of fruit of plants of hybrid variety F1 M and Mo is illustrated in Figure-25.

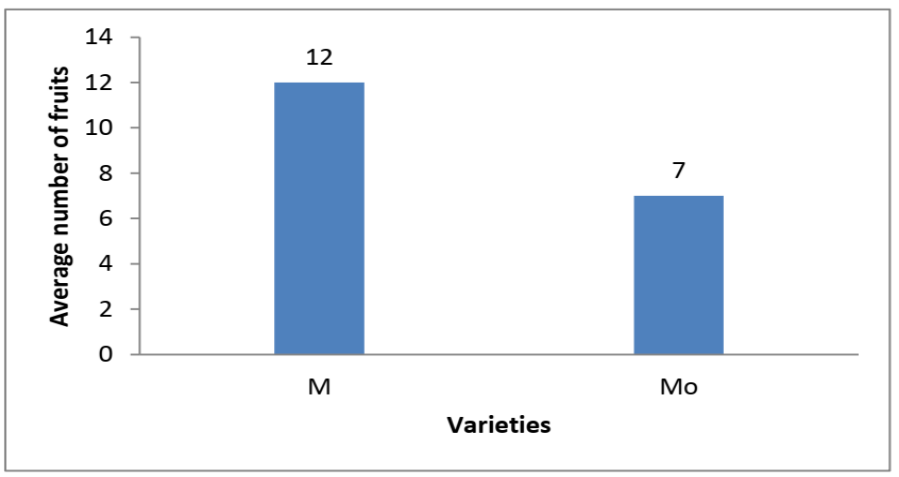

Fig-25: Average number of fruit of plants of hybrid variety F1 M and Mo

It appears from this figure 25 that the average number of fruit was higher in the variety $\mathrm{M}$ cultivated in the soil enriched with sawdust (12 fruits) than in its control ( 7 fruits). The student's test shows that there is no significant difference $(\mathrm{p}$-value $=0.21>0.05)$.

By comparing with the results of Bokokolo [33], which found in the variety Marmande (9.6 fruits).
This number is less than the variety $\mathrm{M}$ and is greater than the same variety considered as control Mo. These differences are due to genotypes and environmental conditions.

\section{Average fruit weight per plant}

The average fruit weight for the hybrid variety F1 M and its control (Mo) is illustrated in Figure-26.

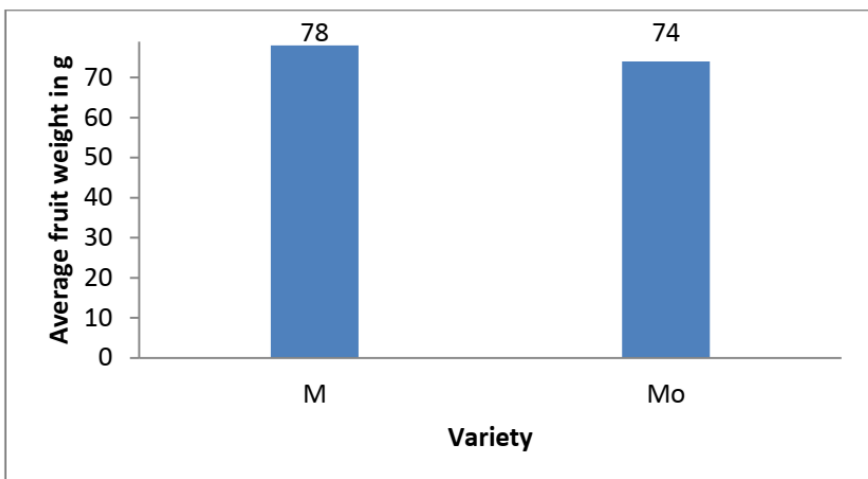

Fig-26: Average weight of fruit for the hybrid variety F1 M and of witness Mo 
It appears from this figure 26 that the variety $M$ cultivated in the enriched soil produced heavier fruits $(78 \mathrm{~g})$ than its control Mo $(74 \mathrm{~g})$. These average numerical values tested by the student statistical test indicate that there is no significant difference ( $\mathrm{p}$ - value $=0.72>0.05 \%)$. In relation to the results of Lokonga [16], which found in fruits of the hybrid variety F1
(15.23 g) of group XI. This average weight is less than variety $\mathrm{M}$ in both conditions. This difference is due to the cultural conditions and the varieties used.

\section{Average number of lodges per fruit}

The number of lodges of hybrid variety F1 M and of control Mo is presented in Fig-27.

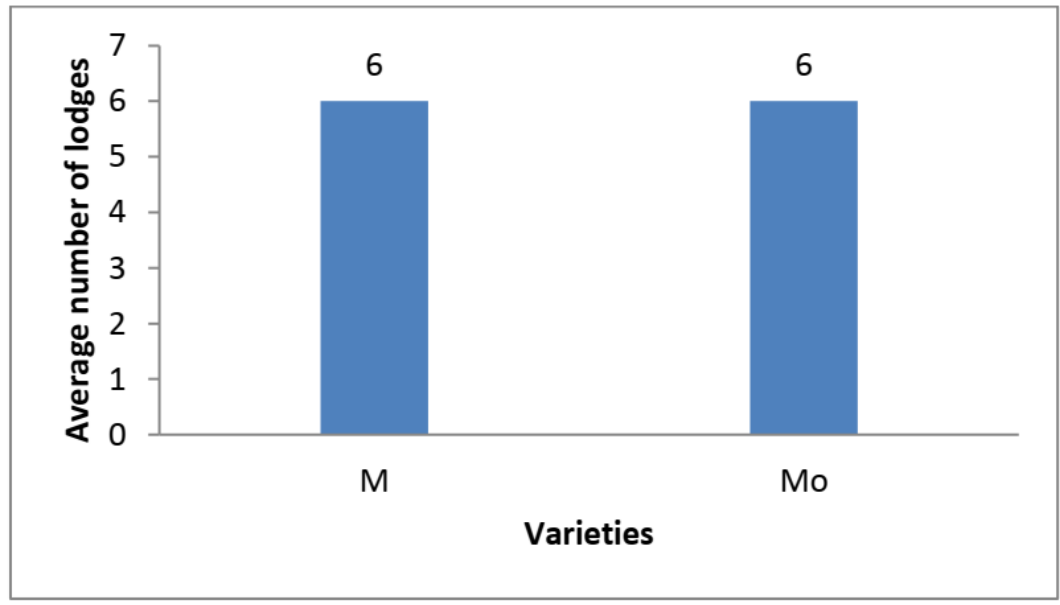

Fig-27: The number of lodges of hybrid varieties F1 M and Mo

It appears from this figure 27 that the number of lodges of the variety $\mathrm{M}$ and of control Mo are identical (6 lodges). These results are different from those of Lokonga [16], who found group XIII for the hybrid variety F1 (2.2 lodges). These differences can be explained by the environmental conditions and the genotypes of the varieties used.

Shape Index

The F1M hybrid variety and Mo control fruit shape index is shown in Figure-28.

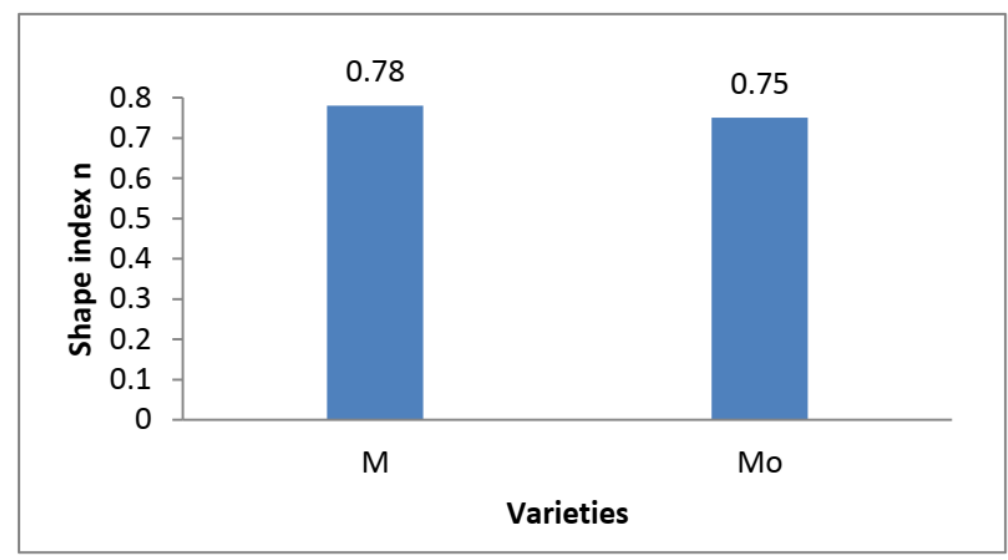

Fig-28: The shape index of the hybrid variety F1 M and M

It appears from this Figure-28 that the shape index varied from 0.75 to 0.78 . Which shows the fruits are flattened.

These results agree with the normal value of the shape index less than 0.8 for the flattened fruits Dossou et al., [30].

\section{Number of well-formed seeds per fruit}

Number of well-formed seeds per fruit of hybrid variety $\mathrm{M}$ and control $\mathrm{Mo}$ is illustrated in Figure-29. 


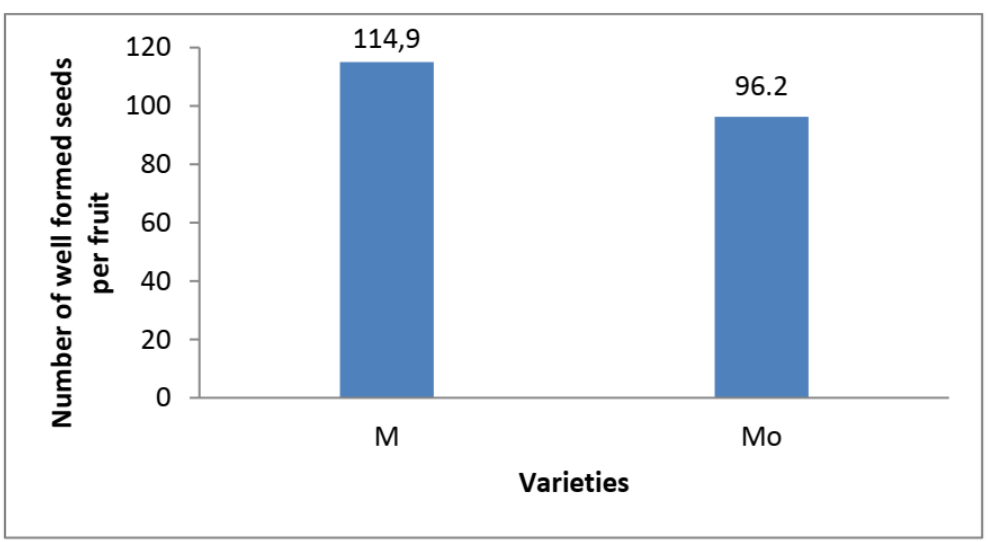

Fig-29: Number of well-formed seeds per fruit of hybrid variety $M$ and Mo

Analysis of this figure 29 shows that the number of well-formed seeds varied from (96.2 to 114.9 seeds). Fruits of the same variety $M$ grown in soil enriched with sawdust formed more seeds than the control.

By comparing our results with those of Bokolo [33], who obtained in the variety MARMANDE (125.2 seeds), higher number of seeds than $\mathrm{M}$. This difference is due to genotypes and environmental conditions.

\section{Plot Production}

The plot production of hybrid variety F1 M and Mo is illustrated in Figure-30.

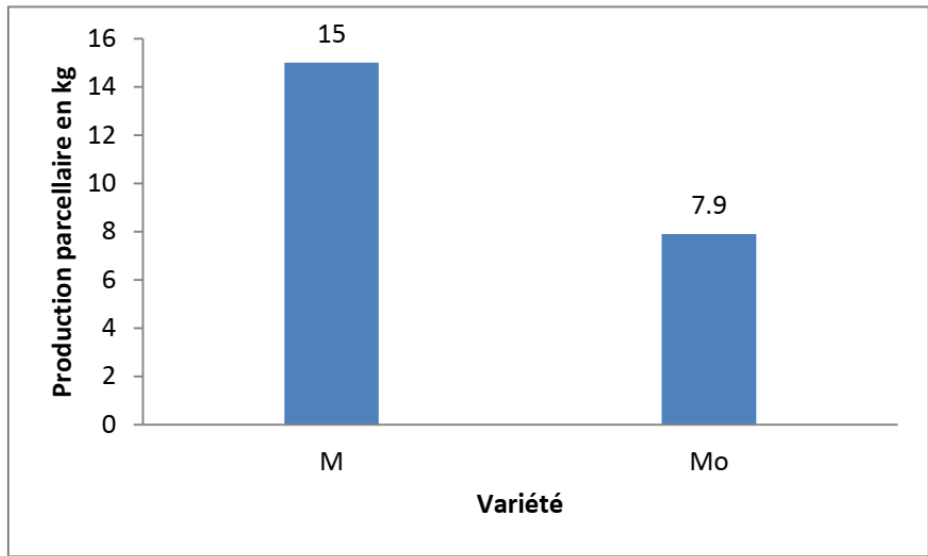

Fig-30: The plot production of hybrid variety F1 M and control Mo

It emerges from this figure 30 that the plot production of hybrid variety $\mathrm{M}$ and its control (Mo) that variety $M$ varied from 7.9 to $15 \mathrm{~kg}$. Hybrid $\mathrm{M}$ grown in enriched soil had the highest plot production $(15 \mathrm{~kg})$ compared to its control $(7.9 \mathrm{~kg})$.

\section{Yield}

The yield of fruits of hybrid variety F1 M and of control Mo is presented in Fig-31.

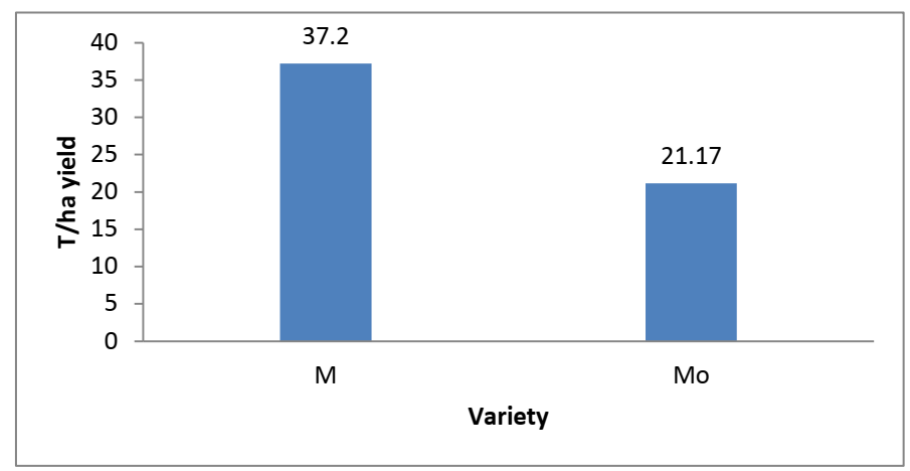

Fig-31: Yield of F1 M hybrid variety fruit and Mo control 
It appears from this Figure-31 that the yield of the variety $M$ cultivated in the amended soil of sawdust is higher (37.2 $\mathrm{t} / \mathrm{ha}$ ) compared to its control Mo (21.17 $\mathrm{t} / \mathrm{ha}$ ). This difference is due to the cultural conditions (sawdust).
By comparing our results with those of [34], who have found for the variety $M$ cultivated in the soil enriched with pig manure $(15.11 \mathrm{t} / \mathrm{ha})$. These deviations may be due to environmental conditions.

Table-1: Summary of the Quantitative Characters of Two Varieties and Their Witnesses

\begin{tabular}{|l|l|l|l|l|l|l|}
\hline \multirow{2}{*}{ Varieties } & \multicolumn{6}{l|}{ Characters } \\
\cline { 2 - 7 } & Zise & Flower & Fruit & weight & Plot production & Yield \\
\hline T & 127,7 & 39 & 6 & 92 & 8,1 & 21,6 \\
\hline M & 143 & 46 & 12 & 78,4 & 15 & 37,2 \\
\hline To & 128,4 & 58,7 & 6,2 & 93 & 9,4 & 22,94 \\
\hline Mo & 119 & 31 & 7,3 & 74,9 & 7,9 & 21,17 \\
\hline
\end{tabular}

Table-1 shows that the size of plants varied from 127.7 to $143 \mathrm{~cm}$ in the two hybrid varieties $\mathrm{F} 1 \mathrm{~T}$ and $\mathrm{M}$ cultivated in soil enriched with sawdust. The variety $\mathrm{M}$ presented the highest size compared to $\mathrm{T}$.

For the variety $\mathrm{T}$ and its control, the control showed the size slightly high $(128.4 \mathrm{~cm})$ compared to $\mathrm{T}$ cultivated in the enriched soil (127.7). As for the size of the variety $M$ and its control, $M$ cultivated in the enriched soil has the highest size.

With regard to the average number of flowers, the witness to formed more flowers (58.7 flowers);

The variety $M$ cultivated in the amended soil developed more flowers (46 flowers) than the control (Mo: 31 flowers). With regard to the average number of fruit, the variety $M$ cultivated in the enriched soil had more fruits (12) than the variety $\mathrm{T}$ and the controls. As for the average fruit weight, witness to developed heavier fruits $(93 \mathrm{~g})$ than $\mathrm{T}$ and $\mathrm{M}$ grown in soil enriched with sawdust.

Regarding the plot production, the variety $\mathrm{M}$ cultivated in the soil enriched with sawdust produced more $(15 \mathrm{~kg})$ compared to its control to $(9.4 \mathrm{~kg})$ and finally, for yield, the variety $M$ cultivated in soil enriched with sawdust is greater (37.2 t / ha) than variety $\mathrm{T}$ cultivated in soil enriched with sawdust. The control to is slightly superior to the variety $\mathrm{T}$ cultivated in the soil enriched with sawdust and to the control Mo.

\section{CONCLUSION}

The general objective of this work was to compare 2 varieties (genotypes) in the same environment (in soil enriched with decayed sawdust) in order to detect the most efficient. These are the foreign F1 (Thorgal and Mongal) hybrid varieties of tomato (Solanum lycopersicum L.) grown under cover in Kisangani. The specific objective was to detect the best performing hybrid variety F1 for using sawdust. Both were evaluated according to the randomized block system at the rate of 3 repetitions per plot.
The analysis of quantitatives characters led us to the following results: For the F1 hybrid varieties (THORGAL and MONGAL) cultivated in the amended soil of pig manure:

- The average size of plants was higher in the $\mathrm{M}$ variety $(143 \mathrm{~cm})$ and lower in the $\mathrm{T}$ variety $(127.7 \mathrm{~cm})$;

- The number of flowers was higher in variety M (46 flowers) and lower in variety $\mathrm{T}$ (39 flowers);

- The number of fruits was higher for variety $\mathrm{M}$ (12fruits) and lower for variety $\mathrm{T}$ (6fruits);

- Plot production was higher in variety M (15 $\mathrm{kg})$ and lower in variety $\mathrm{T}(8.1 \mathrm{~kg})$ and

- Variety M gave a higher yield (37.2 t / ha) compared to variety T (21.6t / ha). Concerning the cultivar F1 THORGAL cultivated in the soil enriched with sawdust and its witness:

- The average size of plants was the same for both the variety $\mathrm{T}$ and its control To $(128 \mathrm{~cm})$;

- The number of flowers was higher in the control To (58 flowers) than in $\mathrm{T}$ (39 flowers) cultivated in the soil amended with sawdust;

- The number of fruits was the same for variety $\mathrm{T}$ and its control To (6 fruits);

- The plot production was higher in the control To $(9.4 \mathrm{~kg})$ than in the same variety $\mathrm{T}(8.1 \mathrm{~kg})$ cultivated in the amended soil of sawdust;

- The yield was slightly higher in the control (To $=22.97 \mathrm{t} / \mathrm{ha})$ than in the same variety $\mathrm{T}(21.6$ $\mathrm{t} / \mathrm{ha}$ ) cultivated in soil enriched with sawdust. As for the hybrid variety F1 MONGAL cultivated in the soil enriched with sawdust and its witness

- The average size of plants was higher in the variety $\mathrm{M}(143 \mathrm{~cm})$ and lower than its control Mo $(119 \mathrm{~cm})$;

- The number of flowers was higher in variety M (46 flowers) and less in control Mo (31 flowers);

- The number of fruits was higher in variety $\mathrm{M}$ (12fruits) and lower in control Mo (7fruits);

- the plot production was higher in the variety $\mathrm{M}$ $(15 \mathrm{~kg})$ and less in its control Mo $(7.9 \mathrm{~kg})$ and 
- The yield was higher in variety M (37.2 t / ha) than in its control Mo (21.17 t / ha). The student statistical test carried out between the quantitatives characters of two varieties showed that there is no significant difference ( $p$-value $>0.05$ ). At the end of these results, we suggest: for the next studies

- Cultivate the same varieties by varying the quantities of sawdust from the sheltered woods

- Compare the yields of the cultivation of these varieties under cover and in the field

- Combine the application of sawdust with rice husks, manure, and so on.

- Determine the nutritional values of the fruits of these varieties grown in soil enriched with sawdust.

\section{REFERENCE}

1. Causse, M., Duffe, P., Gomez, M. C., Buret, M., Damidaux, R., Zamir, D., ... \& Rothan, C. (2004). A genetic map of candidate genes and QTLs involved in tomato fruit size and composition. Journal of Experimental Botany, 55(403), 1671-1685.

2. Bai, Y., \& Lindhout, P. (2007). Domestication and breeding of tomatoes: what have we gained and what can we gain in the future?. Annals of botany, 100(5), 1085-1094.

3. How Kit, A. (2008). Contrôle épigénétique du développement et de la qualité des fruits de tomate (Doctoral dissertation, Bordeaux 1).

4. Seymour, G., Poole, M., Manning, K., \& King, G. J. (2008). Genetics and epigenetics of fruit development and ripening. Current opinion in plant biology, 11(1), 58-63.

5. Mounet, F., Moing, A., Garcia, V., Petit, J., Maucourt, M., Deborde, C., ... \& Giraudel, J. L. (2009). Gene and metabolite regulatory network analysis of early developing fruit tissues highlights new candidate genes for the control of tomato fruit composition and development. Plant Physiology, 149(3), 1505-1528.

6. Djidji, A. H., Zohouri, G. P., Fondio, L., Nzi, J. C., \& Kouame, N. C. (2010). Effet de l'abri sur le comportement de la tomate (Solanum lycopersicum L.) en saison pluvieuse dans le Sud de la Côte-d'Ivoire, www.biosciences.elewa.orgo.

7. Barrero, L. S., \& Tanksley, S. D. (2004). Evaluating the genetic basis of multiple-locule fruit in a broad cross section of tomato cultivars. TAG Theoretical and Applied Genetics, 109, 669679.

8. Cong, B., \& Tanksley, S. (2006). FW2.2 and cell cycle control in developing tomato fruit: a possible example of gene co-option in the evolution of a novel organ. Plant Molecular Biology, 62, 867880.

9. Semel, Y., Nissenbaum, J., Menda, N., Zinder, M., Krieger, U., Issman, N., ... \& Zamir, D. (2006).
Overdominant quantitative trait loci for yield and fitness in tomato. Proceedings of the National Academy of Sciences, 103(35), 12981-12986.

10. Causse, M., Chaib, J., Lecomte, L., Buret, M., \& Hospital, F. (2007). Both additivity and epistasis control the genetic variation for fruit quality traits in tomato. Theor Appl Genet 115, 429-442.

11. De vienne, D., \& Fievet, J. (2009). L'hétérosis: Etat des connaissances dans le sélectionneur Français, 60, 5-20.

12. Ranc, N. (2010). Analyse de polymorphisme moléculaire de gènes de composantes de la qualité des fruits dans les ressources génétiques sauvages et cultivées de tomate; recherche d'associations gènes/QTL. Thèse de doctorat, école nationale Supérieure Agronomique de Montpellier, 261.

13. Clarissia, R., \& Christian, M. (2009). Amélioration génétique de la tomate (Lycopersicon spp.) inéd. Ecole supérieure des sciences Agronomique, 17.

14. Lozano, R., Giménez, E., Cara, B., Capel, J., \& Angosto, T. (2009). Genetic analysis of reproductive development in tomato. International Journal of Developmental Biology, 53(8-9-10), 1635-1648.

15. Massot, C. (2010). Analyse des variations de la teneur en vitamine $\mathrm{C}$ dans le fruit de tomate et rôle de l'environnement lumineux, thèse de doctorat, Université D’Avignon et des Pays de Vaucluse, 192.

16. Lokonga, O. (2015). Essai d'hybridation entre les formes locales et variétés introduites en vue de l'obtention de génotypes nouveaux de tomate (Solanum lycopersicum L.) adaptés aux conditions écologiques de la région de Kisangani (R.D.Congo), Thèse de doctorat, Unikis, 335.

17. Doganlar, S., Frary, A., Ku, H. M., \& Tanksley, S. D. (2002). Mapping quantitative trait loci in inbred backcross lines of Lycopersicon pimpinellifolium (LA1589). Genome, 45(6):1189-202.

18. Bintou F., Diouf H., Mergeai G., (2012). Distorsions de ségrégation et amélioration génétique des plantes (synthèse bibliographique), Biotechnol. Agron. Soc. Environ., volume 16 numéro 4, pp 499-508.

19. Jugdé, H., Adam, H., Bezançon, G., Pham, J. L., \& Vigouroux, Y. (2010). Genetic basis of pearl millet adaptation along an environmental gradient investigated by a combination of genome scan and association mapping. Molecular ecology.

20. UNIFA (union des industries de la fertilisation). (2015). Intérêts de la fertilisation organique; 2425.

21. Weterings, K., \& Russell, S. D. (2004). Experimental analysis of the fertilization process. Plant Cell, 16, 107-118.

22. Luu, D. T., \& Maurel, C. (2005). A quaporins in challenging environment. 
23. Prat, R. (2007). Experimentation in vegetable biology and physiology, ed. Quae, 296.

24. Hommel, M. (2007). La régulation transcription elle de l'expression génique dans le fruit de tomate: caractérisation fonctionnelle de promoteurs fruit-spécifiques et d'un cofacteur de la transcription de type MBF1. Thèse de doctorat, Institut National Polytechnique de Toulouse, 1-25.

25. Reymond, M., Muller, B., Leonardi, A., Charcosset, A., \& Tardieu, F. (2003). Combining quantitative trait loci analysis and an ecophysiological model to analyse the genetic variability of the responses of leaf growth to temperature and water deficit. Plant Physiology, 131, 664

26. Scarlat, A. (1978). Temperature depend pollen and polen tube elongation in some culture plants. Ann. Univ. Bucaresti. S. Biologie, Annul. XXVII, 8388.

27. Tarchoun, N., Chalbi, H., \& Harzallah, H. (1993). Etude de la viabilité des gamètes et sélection de lignées pour la nouaison à haute température chez la tomate de saison (Lycopersicon esculentum) en tunisie Ed. AUPELF-UREF. John Libbey Eurotext, paris, 271- 281.

28. Zahra, A. (2002). Altération de l'expression génétique de la tomate (lycopersicon esculentum) par transfert de gènes induits par la sécheresse chez Lycopersicon Chilense, thèse de doctorat, Université du Québec à Montréal, 1-78.
29. Gaufichon, L., Prioul, J, L., \& Bachelier, B. (2010). Quelles sont les perspectives d'amélioration génétique de plantes cultivées tolérantes à la sécheresse? in FARM (fondation pour l'agriculture et la ruralité dans le monde, 61 .

30. Dossou, J., Soulé, I., \& Montcho, M. (2007). Evaluation des caractéristiques physico-chimiques et sensorielles de la purée de tomate locale produite à petite échelle au Bénin. Tropicultura, 25(2), 119-125.

31. Conti, S., Leoni, C., Monti, L., \& Silvestri, G. (1981). Une méthode d'évaluation de la tomate de conserve. génétique et Sélection de la tomate, INRA, 65-74.

32. Fagbohoun, O., \& Kiki, D. G. (1999). Aperçu sur les principales variétés de tomate locale cultivées dans le sud du Bénin. Bulletin de la Recherche Agronomique Numéro.

33. Bokolo, B. (2002). Analyse génétique de quelques lignées de la génération F8 issus du croisement de la variété étrangère (Marmande) et d'une forme de la variété locale (Rouge-ronde) de Solanum lycopersicum L. et essai de rétrocroisements à Kisangani.

34. Lokonga, O., \& Kamara, M. (2016). Effet de fumier de porc sur le rendement de deux génotypes hybrides F1 (Mongal et Thorgal) exotiques de tomate (Solanum lycopersicum L.) cultivées sous abri à Kisangani, 42. 